THINKING ORDER SKILLS OF READING COMPREHENSION QUESTIONS IN ENGLISH TEXTBOOK FOR ELEVENTH GRADE OF SENIOR HIGH SCHOOL BASED ON BLOOM'S TAXONOMY

\author{
AN ARTICLE \\ Submitted to Partial Fulfillment of the Requirement \\ for the Degree of Sarjana Pendidikan
}

By:

NURASIAH LUBIS

Registration Number: 2122121027

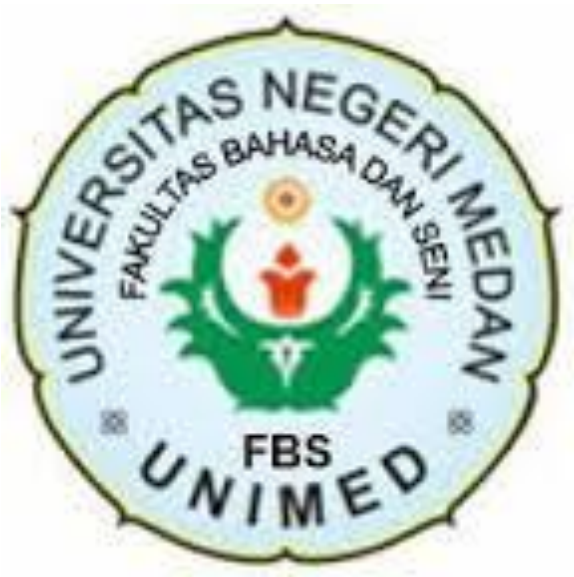

ENGLISH AND LITERATURE DEPARTMENT

FACULTY OF LANGUAGES AND ARTS

STATE UNIVERSITY OF MEDAN

2016 
ARTIKEL

THINKING ORDER SKILLS OF READING COMPREHENSION QUESTIONS IN ENGLISH TEXTBOOK FOR ELEVENTH GRADE OF SENIOR HIGH SCHOOL BASED ON BLOOM'S TAXONOMY

\author{
Disusun dan Diajukan oleh: \\ NURASIAH LUBIS \\ NIM. 2122121027 \\ Telah diverifikasi dan dinyatakan memenuhi syarat \\ Untuk diunggah pada jurnal online \\ Medan, $\quad$ September 2016
}

Menyetujui

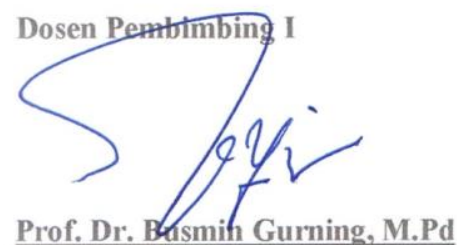

NIP. 195907131986011001
Dosen Pembimbing II

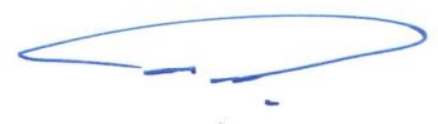

Dra.Masitowarni Siregar, M.Ed NIP. 196711021993032001

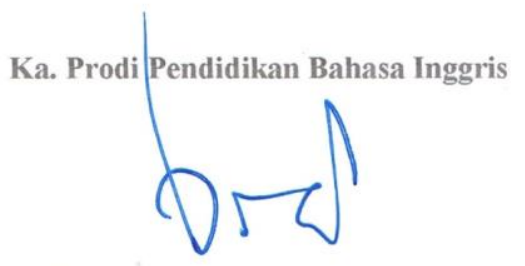

Nora Ronita Dewi, S.S., M.Hum NIP. 198005222008122003 


\title{
THINKING ORDER SKILLS OF READING COMPREHENSION QUESTIONS IN ENGLISH TEXTBOOK FOR ELEVENTH GRADE OF SENIOR HIGH SCHOOL BASED OF BLOOM'S TAXONOMY
}

\author{
*Nurasiah Lubis \\ **Busmin Gurning \\ **Masitowarni Siregar
}

\begin{abstract}
Nurasiah Lubis. Registration Number: 2122121027. Thinking Order Skills of Reading Comprehension Questions in English Textbook for Eleventh Grade of Senior High School Based on Bloom's Taxonomy. A Thesis. English Educational Program, State University of Medan, 2016.
\end{abstract}

The objective of this study aimed to analyzing higher order thinking skills of reading comprehension questions in English textbook for eleventh grade of senior high school. It also used qualitative research method for collected, analyzed and classified reading questions based on revised of Bloom's Taxonomy. The data of this study were taken from reading comprehension questions in Contextual English textbook. The findings showed that the distribution of the higher order thinking skills looks like: the analyze skill obtains 20 out of 155 reading comprehension questions $(12.9 \%)$ while the evaluate skill only obtains 4 out 155 questions $(2.6 \%)$ and the create skill obtains 2 out of 155 questions $(1.2 \%)$. The dominant level of the higher order thinking skills contained in analyze skill (12.9\%). These results do not achieve proportion of thinking order skills namely $30 \%$ for $\mathrm{C} 1$ and $\mathrm{C} 2,40 \%$ for $\mathrm{C} 3$ and C4, and 30\% for C5 and C6. It shows that the distribution of the higher order thinking skills in the reading comprehension questions in Contextual English textbook is unequal.

Key words: English language textbook, reading comprehension questions, revised edition of Bloom's Taxonomy.

\footnotetext{
*Graduate Status

***ecturer Status
} 


\title{
INTRODUCTION
}

\author{
Background of the Study
}

English is very important to be learned because it becomes an international language is used by people around the world to communicate each other. Indonesian students learn English as a foreign language because it becomes a subject. It is used in English classrooms but not in everyday communication. Classroom teaching consists of three main elements: the teacher, the student and the textbook. As one of elements in learning process, the textbook plays important part in English teaching and learning process. Muchlis (2015: 314) state that English textbook is the most commonly resource used in English language teaching process. Textbook plays important role in teaching and learning process because it provides beneficial guidance and covers the materials that teachers need to deliver.

In English textbook there are four skills that must be learned by students, they are: listening, speaking, reading and writing. As a skill, reading is clearly one of important language skill that where students have to read English material for their subject. Through reading, the students get more information and more easily to understand the sentences. They also can improve their knowledge by reading. The students should be known what they read, so they can get a point what they need. By the reading, the reader expected get information. Actually, the students often thought to be easier to get information from written text by reading. In fact, the students will get the problems if they do not comprehending a text and they do not get information from the text. Besides, their vocabulary and their reading skills to comprehend the text or sentences still need to improve. 
Besides, reading comprehension questions assist the students to comprehend the sentences. Yusak in Fitria et.al (2014: 3) stated that question in the reading class is not to test the students, however, it is used to make students aware of the way language is used to convey meaning and of the strategies he can use to recover the meaning from the text. By answering the question, students can think critically and use different level of thinking order to get whole comprehension.

Therefore, the students need levels thinking to answer the questions to understand and comprehend about the text. Gunning in Fitria et.al (2014:4) stated that taxonomies are appropriate indicators of the relative position that questions occupy on a scale of complexity. Test questions should be examined to make sure higher levels of questions being asked.

The English textbook entitle "Contextual English" for the eleventh grade of senior high school written by Bambang Sugeng and Noor Zaimah published by Platinum. The textbook is based on Educational Unit-Oriented Curriculum (Kurikulum Tingkat Satuan Pendidikan) 2006.

From the textbook page 158, a text which the title is A Telephone Call and the reading exercise questions is as follows:

1. What is the story about?

2. What was the speaker doing?

3. To whom that the speaker speak?

4. In some part of story, the speaker counted something. What did she exactly do?

5. Did the speaker finally do what she intended to do?

From the reading exercise questions above not indicate to higher order thinking skill because the exercise questions still depend to the text and the exercise questions not help the students to use their critical thinking. Moreover the higher order thinking level should allow the students to gives more insight into their thinking and learning to answer like the essay questions, the students need to use their own words. It is reasonable step to 
analyze the reading question exercise another one in the textbook, whether the textbook appropriate with the level of Bloom's Taxonomy or not and this research can help the teacher to organize the reading exercise questions which is help the students to think critically.

It is very important for the teacher to choice and selecting a textbook which is appropriate for the students to develop their thinking skills by using analysis thinking order skills of reading comprehension questions in English textbook based on Bloom's Taxonomy. To find the result of this analysis, document analysis is needed to know the textbook is appropriate or not with thinking order skills of Bloom's Taxonomy.

\section{REVIEW OF LITERATURE}

Textbook has many advantages for the teachers and the students in teaching and learning process in the classroom. Textbook can be useful for accomplishing comprehensions about materials through tasks and exercise. As the exercises, the teachers use questions to find out whether the students have understood the text or not, especially in reading comprehension.

Reading comprehensions usually follow by exercises and questions. By answering the question, students can think critically and use different level of thinking order to get whole comprehension. Therefore, the students need levels thinking and higher order thinking skills to answer the questions so they can build understand and comprehend about the text.

Higher order thinking useful for creating meaningful learning in teaching and learning process because it gives broader comprehension of learning, not only acquiring knowledge but also being able to use the knowledge in situations students' everyday 
life. It is important for the students because it can help and support the students in improving their ability in the higher order thinking skill.

Bloom's taxonomy is appropriate to apply in reading comprehension questions to helping students to have critical thinking. Bloom's taxonomy offers six levels of thinking namely knowledge, comprehension, application, analysis, synthesis, and evaluation. Thinking order in Bloom's Taxonomy are helping students to learn something in meaningful process and improving the students' overall performance. Higher order thinking skills require that we apply the facts that we learn. These skills are commonly defined based on Bloom's Taxonomy, which examines and categorizes different levels of thinking. In order to promote higher order thinking skill within the classroom, students must not only have a basic knowledge and comprehension of concepts but be able to apply what they are learning through hands on activities.

\section{RESEARCH METHODOLOGY AND FINDINGS}

\section{Methodology}

The method of this study is qualitative research. According to Bogdan and Biklen (1998: 5) the written results of the research contain quotations from the data to illustrate and substantiate the presentation. The data include interview transcripts, field notes, personal documents, memos, and etc.

In collecting the data in this research, the writer use document analysis. Ary, Donald and et.al (2010 : 457) stated that document analysis is a research method applied to written or visual materials for the purpose of identifying specified characteristics of the material, the materials analyzed can be textbook, newspaper, web page, etc. 


\section{Techniques of Analyzing the Data}

The writer use qualitative research by Bogdan and Biglen (1998: 157) to analyze the data. There are three steps to analyzing data through these following steps:

1. Organizing and managed the data, reducing or limited the data and focus of the study

2. Synthesizing the data, examine all the data with same code and merge them in one category

3. Discovering the data, what is important and what is to be learned of the findings.

\section{Findings}

The analysis revealed that the higher order thinking skills existed in the textbook written by Bambang Sugeng and Noor Zaimah is created for Senior High School and MA Grade XI (General Program). After analyzing the textbook, the findings of this study could be seen below.

1. From 15 chapters in the textbook, there are 155 reading questions in the textbook yet the higher order thinking level gets 26 questions while the lower order thinking level gets 129 questions. It might happen because the lower order thinking questions are familiar appeared in the textbook.

2. The distribution of the higher order thinking questions show that the evaluate skills only gets $2.6 \%$ out of $100 \%$ and the create skills obtains $1.2 \%$ distribution. It is quite surprising if comparing to another research by Seif (2012: iii) which found that the synthesis skill or create skill obtains an excellent number, $41.35 \%$. It might happen because the questions look much more complex than the lower order thinking level. 
3. The distribution of higher order thinking skills is $16.7 \%$ and the lower order thinking skills obtains $83.2 \%$. For the analyze skills obtains $12.9 \%$, while evaluate skill obtains $2.6 \%$ and for the create skill obtains $1.2 \%$, and the dominant level is contained in analyze skill. The first skill in the higher order thinking level, the analyze skill obtains 20 questions out of 155 questions or 12.9\%. It might happen because Brookhart (2010:42) points out that it is a must to create such questions that ask the students to describe and figure out how one thing to others are related.

4. Then, the second category is the evaluate skill. There are 4 questions out of 155 or $2.6 \%$ which belong to the evaluate skill, the last category is the create skill available in the 2 chapters in the textbook, chapter 2 and 8 . There is only 1 question for each chapter.

\section{CONCLUSION AND SUGGESTIONS}

\section{Conclusion}

Based on the data analysis of research in textbook for eleventh grade of senior high school, the writer wants to present the conclusions. The conclusions consist of several points that are related to the problems of the study.

1. The distribution of the higher order thinking skills looks like:

- The analyze level gets the highest number by obtaining 20 out of 155 questions or $12.9 \%$

- The evaluate level, obtain 4 out of 155 question or $2.6 \%$, and

- The create level, the most critical thinking skill, obtains 2 out of 155 questions or $1.2 \%$. 
2. It can be concluded that the dominant level of higher order thinking in textbook contain in analyze skill gets 20 items out of 155 or $12.9 \%$.

3. The higher order thinking skill is not properly available in Contextual English textbook, and inappropriate with thinking order skills of Revised of Bloom's Taxonomy.

\section{Suggestions}

Considering the conclusions above, some suggestions are presented in this past. As discussed in chapter I, this study hopefully can give advantageous information both theoretically and practically.

1. The English teacher should train the students to improve their critical thinking or higher order thinking skill so that their higher order thinking skill could be better.

2. The English teacher need modify question items on reading comprehension by including level of analysis, evaluation and create while teaching in classroom.

3. The English teachers need to check the material and the exercises of the textbook are appropriate for the students' thinking level.

4. The authors and publisher of English textbook more complete the order thinking by enriching some exercise which could train the students to have the higher order thinking skill. And developed reading questions that use high order thinking by Bloom's Taxonomy.

5. The readers of this study are hoped to have interest to enlarge their understanding about thinking order skill, and get some references about the textbook selection. 


\section{REFERENCESS}

Anderson, L., \& Krathwohl, D. R. 2001. A taxonomy for learning, teaching, and assessing: a revision of Bloom's Taxonomy of Educational Objectives. New York: Longman.

Ansary,H, and Babaii,E, 2002. Universal Characteristic of EFL/ESL Textbook: A Step towards System Textbook Evaluation, The Internet TESL Journal, Vol.8, No.2

Ary, Jacobs, and Sorensen.2010. Introduction to Research in Education. Canada: Wadswort

Abdelrahman, M, 2014, "An Analysis of the Tenth Grade English Language Textbooks Questions in Jordan Based on the Revised Edition of Bloom's Taxonomy", Journal of Education and Practice, Vol. 5 No. 18

Bogdan, R.C and Biklen, S. K. 1998. Qualitative Research for Education : an Introduction to Theories and Method.New York : Pearson Education Group

Brookhart,Susan.M. 2010. How to Asses Higher-Order Thinking Skills in Your Classroom. Alexandria: ASCD Member Book.

Cecelia Munzenmaier Cecelia, MS, with Rubin Nancy.2013. PERSPECTIVE Bloom Taxonomy: What's Old is New Again. Scoot Hanson.

Crawley, Sharon J and Merrit, King 2000. Remediating Reading Difficulties. New York: McGraw-Hill.

Day, Richard R and Park, J, 2005. Developing Reading Comprehension Questions. Reading in a Foreign Lnaguage, Vol.17 No.1

Freahat M.Nasser and Smadi M. Oqlah 2014, "Lower-order and Higher-order Reading Questions in Secondary and University Level EFL Textbooks in Jordan", Theory and Practice in Language Studies, Vol. 4, No. 9

Grabe, Willian and L.Stoller Fredricka. 2011. Teaching and Researching, Reading. Britain: Routledge Taylor \& Francis Group

Harmer,J.2007. The Practice English Language Teaching. New York: Longman

Masduki.Subadriah, M.R.Irawan, D.Y. Prihantoro, A. 2013. “ Level Kognitif soal-soal pada Buku Teks Matematika dan Pendidikan Matematika FMIPA UNY,ISBN: 978-979-16353-9-4

Munir,S and Nurkamto,J, 2013, “ An Evaluation of Reading Comprehension Textbooks Taught at the English Education Department of Islamic Higher Education in West Sumatera" journal of language and literature, Vol.7, No.2

Patel.M.F. and Jain. M. Praveen. 2008. English Language Teaching. Jaipur: 
Sunrise Publisher

Sudarsyah, Asep.2013. Manajemen Implementasi Kurikulum: Sisi Lain Ujian Nasional.http://m.kompasiana.com/post/read/543693/1/sisi-lain-dari-un.html. Diakses online 7 Mei 2015 